\title{
Analysis of Tourist Satisfaction with Halal Tourism in Aceh
}

\author{
Harjoni Desky ${ }^{1 *}$, Baverly Thaver $^{2}$, Syamsul Rijal ${ }^{3}$ \\ ${ }^{1}$ Faculty of Islamic Economics and Business IAIN Lhokseumawe, Jl. Medan - Banda Aceh, Alue Awe, \\ Muara Dua, Lhokseumawe, Aceh 24352, Indonesia \\ ${ }^{2}$ University of the Western Cape, Robert Sobukwe Road, Bellville 7535, South Africa \\ ${ }^{3}$ Faculty of Usuluddin and Philosophy Universitas Islam Negeri (UIN) Ar-Raniry, Jl. Syeikh Abdul Rauf \\ Darussalam, Banda Aceh 23111, Indonesia \\ e-mail: harjonidesky@iainlhokseumawe.ac.id*1, bthaver@uwc.ac.za $^{2}$, literasi.syamsulrijal@ar-raniry.ac.id ${ }^{3}$ \\ * Corresponding Author \\ Received: October 11, 2021; Accepted: February 27, 2022
}

\begin{abstract}
Halal tourism has now become a sector that can influence an important role in the economic development of a nation. The purpose of this study is first, to find out how the influence of halal tourism on tourist satisfaction; and second, knowing the satisfaction of tourists visiting Banda Aceh City. The method used in this research is a quantitative method, through a field research approach (field research) is studied to answer the existing hypotheses, the data is analyzed by validity testing, reliability testing, and simple regression testing ( $t$ test) using the SPSS 20.0 application. The results shows there is an influence of halal tourism on the satisfaction of tourists visiting the city of Banda Aceh. This is proved by several assessments which are given by tourists (respondents) who have visited Banda Aceh City in 2018. In addition, the regression results show that the $t$ count $>t$ table, where the $t$ count value is 8.205 while the $t$ table value is 0.201 . It shows that null hypothesis $(\mathrm{HO})$ is rejected and alternative hypothesis (HI) is accepted. It means that there is a significant influence between halal tourism on tourist satisfaction. The coefficient of $R$ Square shows the magnitude of halal tourism effect on tourist satisfaction in Banda Aceh City, with the value of $R$ Square is 0.584. It means that the magnitude of the influence of halal tourism on tourist satisfaction in Banda Aceh City is 58.4 percent and the remaining 41.6 percent is influenced by other factors that are not examined by researchers.
\end{abstract}

Keywords: Aceh, halal tourism, local tourists, tourist satisfaction, tourist visits.

\section{Introduction}

Tourism is a sector that has played a crucial role in economic development of nations around the world. Tourism has become an essential part of human needs or lifestyle. moves people to get to know nature and culture in other countries' regions (Ismayanti, 2020). So that indirectly the movement of people will affect the economic chain that is mutually sustainable into a service industry that contributes to the economy and results in increasing economic welfare at local community level (Pradana, 2019). The expectations of the world community have resulted in spurring the world of tourism to develop themselves, improve services and bring up something new in its development (Pratiwi, 2016).

One of the tourism industries that are currently in demand is halal tourism (Satriana, 2018). Halal tourism is perceived by some as a series of tourism activities that are devoted to facilitating the travel needs of Muslims (Disbudpar Prov. Aceh, 2016). The presence of halal tourism is also the presence of a travel package that refers to the rules of life of Muslims, both in terms of etiquette for traveling, determining tourist destinations, accommodation, and food (Kemenparekraf, 2021). The needs of Muslim tourists for halal tourists generally include the need to worship, get halal food, get added value from travel, and guard against disobedience and evil (Surur, 2020).

Halal tourism is a new trend in the world of tourism today (F.A, May 2020). Indonesia has a role as one of the best halal tourism locations around the world. It is established by its victory on "The World Halal Travel Summit \& EXHIBITION 2015". Indonesia has won three awards, including World Best Family-Friendly Hotel, World Best Halal Honeymoon Destination, and World Best Halal Tourism Destination (Rulloh, 2018). Of course, this reality is the great opportunity for Indonesia to continue to develop halal tourism. In some countries around the world, halal tourism uses several quite diverse named Islamic Tourism, Halal Friendly Tourism Destinations, Halal Travel, Friendly Travel Destinations, Halal lifestyle, and others (Noviantoro, 2020). 
Halal tourism is considered as a new way of developing Indonesian tourism, especially in Aceh, which is supported by Islamic culture and values. Aceh has its concept in developing tourism (Sulaeman, 2019). The province of Aceh is as popular as the Veranda of Mecca. There are many Moelem as the majority. It is also as one of the provinces that popularize tourism. It also has many famous tourist attractions. They have good planning for tourism development. Almost all areas in Aceh have unique tourist attractions that can be used (Eti, 2009).

Aceh has a unique tourism model. It is very influential on the development of tourism itself. The existence of tourism development can also contribute for human's life and the development of Acehnese people. Therefore, many people in the community can get jobs from tourism developments such as selling at tourist spots, being the restaurant employees, being tour guides and hotel employees, being traditional traders and others. Tourism activities are not only activities of moving people from one place to another in a short time (Maulidi, 2019), but moreover, there is a value of worship and support for facilities for them to worship.

Tourist visitors who enjoy the beauty of tourism in Aceh are not only natives but those who come from outside the Aceh area such as from Jakarta, Java, Malaysia, and others (Marefa, 2017). Halal tourism is influental because halal tourism is part of the physical and spiritual needs of human which are guided into the goodness and truth. Also it guided human to stay away from immoral acts, and to keep away from apathetic on Islam instruction (Pandjaitan, 2018). For example, the dress code for being a Muslim or Muslimah. It is hoped that Muslim or Muslimah does not have bad habit or something bad which refers to Islamic Shari'ah. Also it is hoped can become human who has Akhlakul Karimah (Abdillah, 2019).

Aceh is a province that has implemented sharia principles, in which these sharia principles not only regulate matters of worship but also encourage tourism actors to implement sharia-based tourism (Murtini, 2018). The deputy governor from Aceh, Nova Iriansyah, explained the halal tourism has potentials of Aceh in front of the Indonesia-Malaysia-Thailand Growth Triangle (IMTGT) delegation. The exhibition was held at the 23rd IGT meeting, in Pangkal Pinang, Bangka Belitung. The halal tourism market has development in the world, especially in Asia, because of that IMT GT is very important in promoting halal tourism in Aceh. In this case, that Nova explained that the added value for the development of halal tourism in Aceh is that the majority of the population. It is Muslim which has good religious values in human life. In addition, Halal tourism in increasing the number of tourists plays crucial role in increasing the economy.

Improving halal products and services can be done by providing the best quality and standardization of halal certification. Nova Iriansyah also added that connection is one of the keys to encourage growth economic in the IMT-GT region especially to increase tourism growth by opening international flight route to make it become easier for tourists who wants to visit Aceh. Strengthening connectivity is very important in supporting the development of the tourism market. He gave an example of direct flights from Penang to Banda Aceh, Kuala Lumpur to Banda Aceh, and Singapore to Banda Aceh. The strengthening of connectivity cannot be separated from the improvement of infrastructure, which is currently being carried out in Aceh with the construction of the Sumatran Toll road (Khairullah, 2017).

The Aceh government through the tourism office has tried to develop halal tourism in Aceh in order to realize the satisfaction of visiting tourists, including by building facilities and infrastructure for worship, separation of facilities between men and women, labeled halal food, entertainment in Islamic places while traveling (Abdillah, 2019). Tourists will be satisfied if the aspects of halal tourism received are in line with expectations. On the other hand, the reality on the ground shows that there is still a lack of halal tourism facilities (facilities and infrastructure), limited of human resources. It shows that there are still a lot of homework that have to be finished by the government in developing halal tourism.

Tourist satisfaction is one of the benchmarks for assessing the success of the development of halal tourism in Aceh. At first, the purpose of this study is to find out how the influence of halal tourism on tourist satisfaction. Second, it is to know the satisfaction of tourists who visited Banda Aceh City. Because of that, this research can contribute in providing the input for local government to maintain and improve the quality of halal tourism and improve the shortcomings that still exist in tourist attractions. Based on this discussion. The authors are interested in researching "Analysis of Tourist Satisfaction with Halal Tourism in Aceh" 


\section{Materials and Methods}

This study uses quantitative method. It is for testing the established hypothesis (Sugiyono, 2012). This research is a type of field research (Field Research) which has done by digging up data sourced from locations or research fields related to the influence of halal tourism on satisfaction of visiting tourists to Banda Aceh City. According to its nature, this research is a descriptive analysis.

The population of this study are local tourists and national tourists who have visited Banda Aceh. The population in this study is unknown. Therefore, the sampling method of this research uses the type of accidental sampling. Anyone who happens to meet the researcher can be used as a sample. If it seen that the person can be used as a sample if it is seen that the person who happened to be met is suitable with the data source (Puguh, 2009). This method is used based on the consideration that the sample was taken from large population to facilitate the research objectives. Therefore, the sample used in the study is part of the population of 50 respondents and the sample taken is tourists who have visited Banda Aceh.The characteristics of the respondents are local tourists who come from another cities of Banda Aceh and Aceh Besar; Tourists who have visited more than once; and Tourists who stayed in Banda Aceh.

The primary data used in this study are the results of the questionnaire. It is used as a sample in the study. Data collection is done by giving questionnaires and observing people and phenomena. There are three main data collection methods in this study, named observing, collecting data through questionnaires, and reviewing relevant literature (Sekaran, 2019).

Data Processing and Analysis Techniques were conducted through validity tests, reliability tests, and classical assumption tests. Hypothesis testing built in this study are:

$\mathrm{H} 1=$ There is a significant influence between halal tourism on the satisfaction of visiting tourists.

$\mathrm{H} 0=$ There is no significant effect between halal tourism on the satisfaction of visiting tourists.

Meanwhile, simple linear regression analysis was used to determine the type of relationship between the variables studied (Riduwan, 2013). The simple regression equation $\mathrm{X}$ against $\mathrm{Y}$ is as follows:

Note:

$$
\mathrm{Y}=\mathrm{a}+\mathrm{b} \cdot \mathrm{X} 1
$$

$\mathrm{a}=$ Number constant

$\beta=$ Number or direction of regression coefficient

$\mathrm{X}=$ Halal Tourism

$\mathrm{Y}=$ Tourist Satisfaction

Coefficient of Determination

To find out how big the contribution of halal tourism to tourist satisfaction $(\mathrm{Y})$, the statistical calculations were carried out using the coefficient of determination $(\mathrm{Kd})$.

Note:

$$
\mathrm{Kd}=\operatorname{ryx}^{2} \times 100 \%
$$

$\mathrm{Kd}=$ Value of the coefficient of determination

ryx $^{2}=$ Correlation coefficient value

\section{Results and Discussion}

\subsection{Characteristics of Respondents}

The data from the results of this study were obtained directly from the distribution of questionnaires to research respondents. Respondents in this study amounted to 50 tourists who visited the city of Banda Aceh. The research locations in this study are places that are often visited by tourists, namely the Banda Aceh Grand Mosque, Aceh Tsunami Museum, Blang Padang field, Mecca Hotel, and Solong coffee. Based on gender, male respondents are the most dominant respondents in this study, namely 30 respondents with a percentage level of $60 \%$. Then followed by women, namely 20 respondents with a percentage level of $40 \%$.

Respondents of this study aged 41-50 are the most dominant totaling 16 respondents with a percentage level of $32 \%$, followed by age 20-30 years totaling 15 respondents with a percentage level of $30 \%$, followed by ages $31-40$ years totaling 14 respondents with a level the percentage of $28 \%$, and $>51$ years, totaling 5 respondents with a percentage level of $10 \%$. Respondents who are married are the most dominant respondents in this study, totaling 37 respondents with a percentage rate of $74 \%$, followed by unmarried respondents, totaling 12 respondents with a percentage rate of $24 \%$, and the last one is those who are widowed/widowed amounting to 1 respondent. with a percentage rate of $2 \%$. 
Respondents whose last education level was SMP/SMA were the most dominant in this study amounting to 20 respondents with a percentage level of $40 \%$, followed by Academy/Diploma totaling 17 respondents with a percentage level of 34\%, followed by Bachelors (S1) 13 respondents with percentage rate of $26 \%$. The most dominant respondents in this study amounted to 14 respondents with a percentage level of $28 \%$, followed by the housewife profession, which amounted to 9 respondents with a percentage level of $18 \%$, followed by the Student/Student profession and civil servants with a total of 8 respondents with a percentage rate of $16 \%$, followed by by the trading profession 6 respondents with a percentage rate of $12 \%$, followed by other professions with a total of 5 respondents with a percentage rate of $10 \%$.

The most dominant respondents in this study amounted to 29 respondents with a percentage rate of 58\%, followed by respondents who visited 4-6 times, totaling 16 respondents with a percentage rate of $32 \%$, and the last one was those who were $>6$ times totaling 5 respondents with a percentage level of $32 \% .10 \%$ percentage. respondents from Aceh are the most dominant respondents in this study, totaling 36 respondents with a percentage rate of $74 \%$, followed by respondents from outside Aceh, totaling 14 respondents with a percentage rate of $28 \%$.

\subsection{Validity and Reliability Test}

Table 1. Result of Validity Test

\begin{tabular}{cllcl}
\hline Variable & \multicolumn{1}{c}{ Question Items } & $\begin{array}{c}\mathrm{R} \\
\text { Count }\end{array}$ & $\begin{array}{c}\mathrm{R} \\
\text { Table }\end{array}$ & Note \\
\hline $\mathrm{X}$ & Halal tourism 1 & 0,619 & 0,278 & Valid \\
& Halal tourism 2 & 0,740 & & Valid \\
& Halal tourism 3 & 0,666 & & Valid \\
& Halal tourism 4 & 0,760 & & Valid \\
\hline $\mathrm{Y}$ & Satisfaction & 0,669 & 0,278 & Valid \\
& traveler 1 & & & Valid \\
& Satisfaction & 0,783 & & Valid \\
& traveler 2 & & & Valid \\
& Satisfaction & 0,813 & & \\
\hline & traveler 3 & & & \\
& Satisfaction & 0,750 & & \\
\hline
\end{tabular}

Source: Data using SPSS 20.0 for Windows

Based on the result (Table 1), it can be explained that the validity coefficient $(R)>r$ table 0.278 , the validity test results can be declared valid, and this research can be continued. The results of the calculations can be seen in the table of SPSS 20 output results below:

Table 2. Reliability Test Results

\begin{tabular}{|c|c|c|c|}
\hline Variable & $\begin{array}{l}\text { Reliability } \\
\text { Coefficient }\end{array}$ & $\begin{array}{c}\text { Cronbach } \\
\text { Alpha }\end{array}$ & Note \\
\hline Halal tourism & $\begin{array}{l}4 \text { items } \\
\text { Question }\end{array}$ & 0,775 & Reliable \\
\hline Traveler's satisfaction & $\begin{array}{l}4 \text { items } \\
\text { Question }\end{array}$ & 0,800 & Reliable \\
\hline
\end{tabular}

Source: Data using SPSS 20.0 for Windows

Based on the result (Table 2), it can be seen that Cronbach's Alpha $>$ than $60 \%(\alpha \mathrm{X}=$ $0.775>0.60 \%$ and $\mathrm{Y}=0.800>0.60 \%)$ then the reliability test results can be stated as reliable or consistent, having a good level of reliability.

\subsection{Biomarker Protein Identification}

\subsubsection{Normality Test}

The results of the normality test in this study showed the Asymp value. Sig. (2-tailed) 0.118> 0.05 so it can be concluded that the data is normally distributed because the significant value in the Kolmogorov-Smirnov table is greater than 0.05 . This can be seen in the following table (Table 3): 
Table 3. Normality Test Results One-Sample Kolmogorov-Smirnov Test

\begin{tabular}{llr}
\hline & & Unstandardized Residual \\
\hline $\mathrm{N}$ & & 50 \\
\hline Normal Parameters & & $0 \mathrm{E}-7$ \\
& Mean & 1.08964113 \\
& Std. Deviation & .168 \\
\hline Most Extreme Differences & Absolute & .096 \\
& Positive & -.168 \\
\hline Kolmogorov-Smirnov Z & Negative & 1.190 \\
\hline Asymp. Sig. (2-tailed) & & .118 \\
\hline
\end{tabular}

Source: Data using SPSS 20.0 for Windows

\subsubsection{Heteroscedasticity Test}

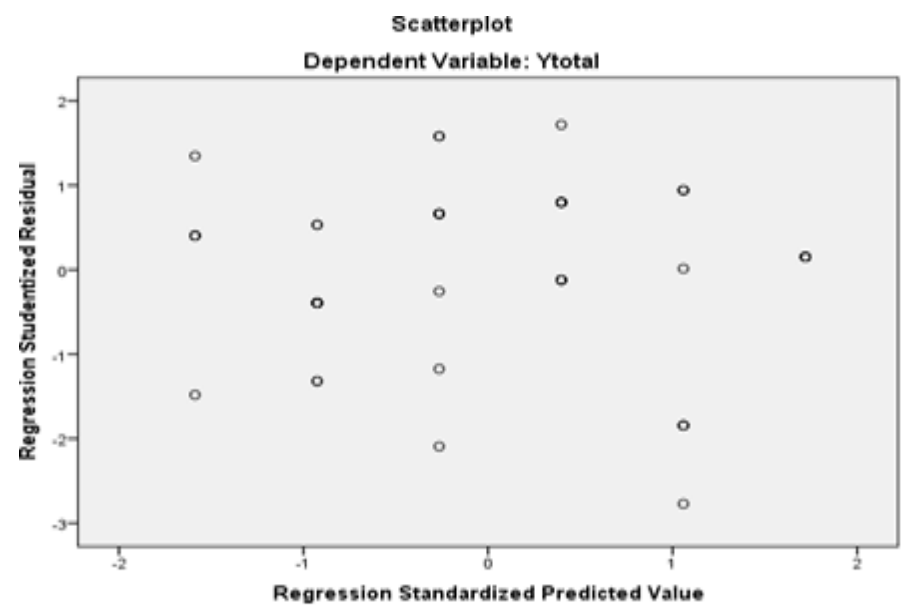

Figure 1. Heteroscedasticity Test Results

Based on Figure 1 the scatterplot graph above can be meaningful, the dots are spread out and do not form a clear pattern. If there is no clear pattern, and the points spread above and below the number 0 on the $\mathrm{Y}$ axis, then there is no heteroscedasticity, so it can be concluded that the absence of heteroscedasticity means that the assumptions in the regression analysis are fulfilled.

\subsubsection{Simple Regression Analysis Results}

The hypothesis is a temporary answer to the formulated problem. Therefore, this provisional answer must be tested empirically for truth. Hypothesis testing in this study was carried out using a simple regression technique for the first hypothesis. The first hypothesis states that "there is a significant influence between halal tourism on the satisfaction of visiting tourists to Aceh". To test this first hypothesis, simple linear regression analysis was used. With the help of the Statistical program series (SPSS) for windows 20.0, a summary of the results of simple linear regression analysis is obtained as shown in the following table:

Table 4. Results of Simple Linear Regression Analysis (Halal Tourism)

\begin{tabular}{lcccc}
\hline \multicolumn{1}{c}{ Variable } & Korf.Regression (B) & t count & Sig. t & Information \\
\hline Constant & 2.768 & 1.523 & .134 & \\
Halal Tourism & .854 & 8.205 & .000 & Significant \\
R Square & .584 & & & \\
\hline Source: Primary data processed, 2022 & & &
\end{tabular}

The results of simple linear regression analysis as in Table 4 above can be written the regression equation as follows:

$$
\mathrm{Y}=\mathrm{a}+\mathrm{b} \cdot \mathrm{X}+\mathrm{e}
$$

Description:

$\mathrm{a}=$ Constant Number

$\mathrm{b}=$ Number direction or regression coefficient

$\mathrm{X}=$ Halal Tourism

$\mathrm{Y}=$ Tourist Satisfaction 
So it can be concluded that the obtained simple linear regression equation is as follows:

$$
\mathrm{Y}=2.768+0.854 \mathrm{X}
$$

The constant value is 2.768 , this means that tourist satisfaction will be 0.854 if halal tourism is zero. This can be explained that tourist satisfaction will decrease if there is no halal tourism. Halal tourism (X1) has a positive influence on tourist satisfaction, with a regression coefficient of 0.854 indicating that if halal tourism increases by 1 percent, tourist satisfaction will increase by 0.854 percent assuming the other independent variables are constant. A significant value (sig) of 0.000 , this value is much lower than 0.05 , so the effect of halal tourism on tourist satisfaction is significant.

Based on the SPSS calculation, the t-count value is 8.205 , while the p-value is 0.000 , so that the $\mathrm{p}$-value is $<5 \%(0.000<0.05)$, meaning that there is a significant effect of the halal tourism variable on the satisfaction of tourists visiting Banda Aceh. These results indicate that the higher the halal tourism, the better the satisfaction of visiting tourists, and vice versa. The coefficient of determination R2 is 0.584 , which means that $58.4 \%$ of the dependent variable of tourist visiting satisfaction can be explained by the independent variable of halal tourism. While the remaining $41.6 \%$ is influenced by variables that are not explained in the model. Thus the first hypothesis which states "there is a significant influence between halal tourism on tourist visiting satisfaction in Banda Aceh" can be accepted.

\subsection{Discussion}

The results of this study indicate that there is a relationship between halal tourism and visitor satisfaction. This explains that halal tourism contributes to the satisfaction of tourist visitors. This visitor satisfaction is because Muslim tourists feel safe and comfortable. Comfort and security here are because tourists do not feel confused anymore in looking for facilities and others, such as prayer rooms or mosques, halal food, and other facilities.

In this case, the Government should continue to increase satisfaction to tourists. One form of satisfaction made by the government and the community towards tourists in Banda Aceh is satisfaction with tourists including adequate facilities for worship, separate facilities for men and women, food hygiene offered to tourists, Islamic entertainment places during the trip. Tourists will be satisfied if the aspects of halal tourism received are in line with expectations.

The results of this study strengthen research from Irda et al. (2019); Sudiartha Athar et al. (2020) \& Ayu et al. (2021) which says that the occurrence of this influence is due to the increasing understanding of tourists about the importance of halal tourism in each city so that people Muslims are no longer worried about their obligations and needs as a Muslim. The most important thing that must be considered by stakeholders is the satisfaction of tourists for tourist attractions, including the presence of prayer rooms, clean bathrooms, and other facilities by Islamic law.

The results of this study say that there is a relationship between halal tourism and tourist satisfaction. This explains that halal tourism affects tourist satisfaction. The better the tourists' assessment of tourist attractions, the higher tourist satisfaction will be (Lisma et al, 2017). A tourist, if he is satisfied with the right tours provided by stakeholders, then it is very likely that tourists will return and participate in promoting these tourist attractions to other tourists. The results of this study are in line with research Nurcahya \& Sugiyanto (2019); Fakhrunissa et al. (2020) \& Sukma Irdiana et al. (2021) which says that tourist satisfaction can shape different consumer behavior at a tourist place. The contribution of the halal tourism variable is indeed very small to satisfy tourists but increasing the understanding of Muslim tourists about the halalness of a tourist place will make tourism now more careful and wiser in determining a tourist attraction that is worth visiting.

\section{Conclusion}

The conclusion of this research is that there is an effect of halal tourism on the satisfaction of tourists visiting the city of Banda Aceh. It is validated from the regression results, the value of $t$ count> $t$ table. The value of $t$ count is 8.205 while the value of $t$ table is 0.201 . null hypothesis (H0) is rejected and alternative hypothesis (H1) is accepted. It means that there is a significant effect of halal tourism on tourist satisfaction. The coefficient of R Square shows the magnitude of the influence of halal tourism on tourist satisfaction in the city of Banda Aceh named the value of $\mathrm{R}$ Square with a value of 0.584 . It means that the magnitude of the effect of halal tourism on tourist satisfaction in Banda Aceh City is 58.4 percent and the remaining 41.6 percent is affected by other factors which did not examined by researchers. 


\section{Acknowledgements}

The researcher would like to thank all the participants who involved of this research, including the respondents who provided an important information in this research.

\section{References}

Abdillah, M. T. (2019). Busana Muslim: Antar Trend Dan Syariat Di Tengah Zaman Modern - Situs Resmi UIN Antasari. Retrieved from https://www.uin-antasari.ac.id/busana-muslim-antar-trenddan-syariat-di-tengah-zaman-modern/

Ayu, D., Puspitasari, K., Pgri, S., \& Korespondensi, D. J. (2021). Analisis Peran Kepuasan Wisatawan Memediasi Pengaruh Atribut Wisata Halal Terhadap Minat Berkunjung Ulang Pantai Syariah Banyuwangi. Jurnal Riset Manajemen Dan Bisnis Dewantara (JMD), 4(1), 45-54.

Disbudpar Prov. Aceh. (2016). Sekilas Tentang Wisata Halal - Dinas Kebudayaan dan Pariwisata Aceh. Retrieved from http://disbudpar.acehprov.go.id/sekilas-tentang-wisata-halal/

Eti, N. Y. (2009). Selayang pandang Nanggroe Aceh Darussalam / Nunung Yuli Eti | OPAC Perpustakaan Nasional RI. Klaten: Intan Pariwara. Retrieved from https://opac.perpusnas.go.id/DetailOpac.aspx?id=532396

F.A., May, et al. (2020). Wisata Halal Trend Baru Industri Pariwisata Korea Selatan. Jurnal Penelitian, 14(1), 153-165.

Fakhrunissa, R. A., Kusdibyo, L., \& Kania, R. (2020). Persepsi Wanita Millennial terhadap Produk Kecantikan Hijau. Prosiding Industrial Research Workshop and National Seminar, 11(1), 1030-1034.

Irda, Yuliviona, R., \& Azliyanti, E. (2019). Pengaruh Islamic Attributes dan Quality Service Terhadap Islamic Tourist Satisfaction Wisatawan Mancanegara yang Berkunjung di Kota Padang. Syi $a r$ Iqtishadi: Journal of Islamic Economics, Finance and Banking, 3(1), 99-113. https://doi.org/10.35448/JIEC.V3I1.5517

Ismayanti. (2020). Dasar-Dasar Pariwisata. Jakarta: Universitas Sahid.

Kemenparekraf. (2021). Potensi Pengembangan Wisata Halal di Indonesia. Retrieved from https://kemenparekraf.go.id/ragam-pariwisata/Potensi-Pengembangan-Wisata-Halal-diIndonesia-

Khairullah. (2017). Makalah Ekonomi Pariwisata tentang Kepariwisataan. Retrieved from https://123dok.com/document/q27025ey-makalah-ekonomi-pariwisata-tentang-kepariwisataankhairullah-disusun-khairullah.html

Lisma, Nuryenti, Yonaldi, Sepris, \& Zulbahri, L. (2017). Faktor-Faktor yang Mempengaruhi Kunjungan Wisatawan ke Objek Wisata Syariah di Sumatera Barat. Jurnal Manajemen Dan Kewirausahaan, 8(1), 38-52.

Marefa. (2017). Prospek Pengembangan Wisata Islami di Banda Aceh. Thesis. UIN Ar-Raniry Aceh.

Maulidi, D. Y. M. (2019). Penilaian Masyarakat terhadap Wisata Halal Pasca Gempa Lombok. Retrieved from https://dspace.uii.ac.id/handle/123456789/14959

Murtini, R. (2018). Pengembangan Wisata Syariah di Kota Banda Aceh. Thesis. UIN Ar-Raniry Aceh.

Noviantoro, K. M. (2020). Prospek Pariwisata Syariah (Halal Tourism): Sebuah Tantangan di Era Revolusi Industri 4.0. EQUILIBRIUM: Jurnal Ekonomi Syariah, 8(2), 275-296.

Nurcahya, Pindar., S. (2019). Pengaruh Destination Branding "Friendly Lombok" terhadap Minat Berkunjung ke Pulau Lombok, Nusa Tenggara Barat. Prosceeding Universitas Pamulung, 1(1), 540-549.

Pandjaitan, D. R. H. (2018). Perilaku Konsumen Indonesia Memilih Destinasi Wisata Halal. Jakarta.

Pradana, G. Y. K. (2019). Sosiologi Pariwisata. Jakarta: STPBI PRESS.

Pratiwi, A. E. (2016). Analisis Pasar Wisata Syariah di Kota Yogyakarta. Media Wisata, 14(1). https://doi.org/10.36276/MWS.V14I1.153

Puguh, S. (2009). Metode Penelitian Kuantitatif untuk Bisnis. Jakarta: Remaja Rosida Karya.

Riduwan. (2013). Metode dan Teknik Menyusun Tesis pengantar Prof.Dr.Buchari Alma. Bandung: Alfabeta.

Rulloh, N. (2018). Pengaruh Kunjungan Wisata terhadap Kesejahteraan Masyarakat Sekitar Objek Wisata Berdasarkan Perspektif Ekonomi Islam (Studi Pada Masyarakat Sekitar Objek Wisata Lumbok Resort Kecamatan Lumbok Seminung Kabupaten Lampung Barat). Thesis. Fakultas Ekonomi Dan Bisnis Islam. http://repository.radenintan.ac.id/3181/

Satriana, E. D. (2018). Wisata Halal: Perkembangan, Peluang, dan Tantangan. Journal of Halal Product and Research (JHPR), 1(2), 32-43. 
Sekaran, U. (2019). Research Method of Business: A Skill Building Approach 8th Edition. Hoboken: Wiley.

Sudiartha Athar, H., Edy Herman Mulyono, L., \& Sutanto, H. (2020). Jurnal ALTASIA Pengaruh Customer Experiences Terhadap Kepuasan Wisatawan Domestik: Peran Mediasi Halal Destination Image. 2(2).

Sugiyono. (2012). Metode Riset Kuantitatif dan Kualitatif - Google Books. Retrieved from https://www.google.co.id/books/edition/Metode_Riset_Kuantitatif_dan_Kualitatif/b_9cEAAAQ BAJ?hl=en\&gbpv $=1 \& \mathrm{dq}=$ Sugiyono. $+(2012) .+$ Metode + Penelitian + Kuantitatif + Kualitatif + dan + R\%26D.+Bandung.+:+Alfabeta\&pg=PA253\&printsec=frontcover

Sukma Irdiana, O., Yunus Ariyono, K., Drmawan, K., Widya, S., \& Lumajang, G. (2021). Pengaruh Wisata Halal terhadap Kepuasan Pengunjung dan Minat Berkunjung kembali. Jurnal Cakrawala Ilmiah, 1(3), 421-428.

Sulaeman, A. R. et all. (2019). Strategi Komunikasi Dinas Kebudayaan dan Pariwisata Provinsi Aceh melalui Program Wisata Halal Wilayah Banda Aceh, Aceh Besar, dan Sabang. Jurnal AlBayan: Media Kajian Dan Pengembangan Ilmu Dakwah, 25(1), 92-115.

Surur, F. (2020). Wisata Halal: Konsep dan Aplikasi. Makassar: Alauddin University Press.

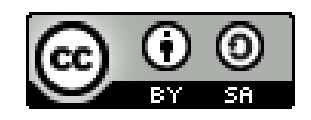

(C) 2022 by the authors. Submitted for possible open access publication under the terms and conditions of the Creative Commons Attribution (CC BY SA) license (https://creativecommons.org/licenses/by-sa/4.0/). 